\title{
Heterogeneous forest structures favor persistence of the grassland Mediterranean geophyte Gagea lacaitae
}

\author{
Hugo Fontes ${ }^{a, b}$, Antoine Gazaix ${ }^{a, c}$ and Guillaume Papuga ${ }^{c, d}$ \\ BOTANY LETTERS, 2019, VOL. 166, NO. 4, 487-498, https://doi.org/10.1080/23818107.2019.1668295
}

${ }^{a}$ Ecosystem department, restauration team, Bouches-du-Rhône, Institut de Recherche pour la conservation des zones humides méditerranéennes Tour du Valat, Arles, France; ' Institut Méditerranéen de Biodiversité et d'Ecologie marine et continentale (IMBE), Bouches-du-Rhône, Avignon Université, UMR CNRS-IRD Aix-Marseille Université, Avignon, France; 'Biodiversity and conservation, Hérault, Centre d'Ecologie Fonctionnelle et Evolutive (CEFE) UMR CNRS 5175, Montpellier, France;

${ }^{\mathrm{d}}$ Conservatoire Botanique National Méditerranéen de Porquerolles, Hérault, antenne Languedoc-Roussillon, Montpellier, France

CONTACT Hugo Fontes fontes@tourduvalat.org, Institut de Recherche pour la conservation des zones humides méditerranéennes Tour du Valat, Le Sambuc, Arles 13200, France

\begin{abstract}
Land use changes in the northern Mediterranean basin threaten our ability to conserve its habitats and species. Reduced grazing has led to local declines in grassland species and colonization by forest species leading to conservation actions aimed at restoring open habitats. Recently, populations of Gagea lacaitae, a bulbous species typical of Mediterranean open xeric grasslands, have been discovered in forest clearings, an unexpected habitat for this species. Here, we surveyed 48 plots to characterize and compare the ecological niche of G. lacaitae growing in both open xeric and forest clearing habitats. We recorded floristic composition and plant cover and collected soil samples to measure water retention capacity, $\mathrm{pH}$, organic matters and conductivity. Open xeric grasslands and forest clearings differ in plant cover, community composition, and microhabitat structure but not in plant diversity, mean soil conditions, or G. lacaitae cover. Key similarities in conditions allow this species to persist in woodlands that heterogenous enough to include clearings. Such habitats have value for conserving this species and should be sustained.
\end{abstract}

\section{Introduction}

Changes in land use have been considered a major threat to biodiversity (Newbold et al. 2015; Sala et al. 2000) and have led many plants to lose their suitable habitats, sometimes leading to local extinction (Lavergne et al. 2005; Falcucci, Maiorano, and Boitani 2007). Land abandonment as a result of changes in agricultural practices was one of the main problems during the 20th century, leading to forest encroachment and the closure of open habitats (Lepart, Fonderflick, and Marty 2014; Blondel et al. 2010; Mazzoleni et al. 2004). Thus, the conservation of open habitats through traditional pastoralism has become a cornerstone of plant conservation in the Palearctic, especially in the northern Mediterranean area (Andrieu, Thompson, and Debussche 2007; Lavergne et al. 2005; Thompson 2005). However, active ecological management to maintain open habitats has suffered recent criticisms and some conservationists support a re-wilding strategy, implying unmanaged forest conservation and free natural successions in temperate Europe and Mediterranean basin (Schnitzler 2014).

The Mediterranean area is a biodiversity hotspot (Myers et al. 2000), comprising $10 \%$ of the world plant richness on 1.6\% of the emerged lands (Médail and Quezel 1997). An important part of those species

is related to open habitats which have persisted thanks to the joint action of grazing by mammals and natural perturbations such as fire (Quezel and Médail 2003). Historically, open grasslands could have also persisted in mosaic with forest due to disturbance and grazing effects of wild large herbivores. The regional extinction of many of them has also probably jeopardized the persistence of natural open grasslands without human influences (Bengtsson et al. 2000; Vera 2000). Since the late Holocene, climatic changes combined with human activities (deforestation and pastoralism intensification) have played a key role in expanding the surface of grasslands and reducing the area of Mediterranean deciduous forest (Jalut et al. 2009; Quezel and Médail 2003).

The south of France represents the north-western limit of the Mediterranean biome (Lenormand et al. 2018). Many species reach their distribution limit as small isolated populations that are of high conservation value (Thompson 2005), most of them living in xeric grasslands (Papuga et al. 2018). Since the mid-20th century, the decline of traditional pastoralism and the reduction of fires intensity have favored the colonization of ancient pastures by ligneous species and trees, which has resulted in a secondary succession mostly dominated by Quercus ilex L. over open Mediterranean xeric grasslands (Perevolotsky and Seligman 1998; Debussche, Lepart, and Dervieux 1999; Quezel and Médail 2003). Thus, many of these open-habitat species were threatened by habitat closure (Farris et al. 2009; Lavergne et al. 2005; Falcucci, Maiorano, and Boitani 2007; Mesléard et al. 2017). 
The genus Gagea exemplifies such issues. It's a well-diversified genus, estimated to contain between 70 and 275 species (Zarrei et al. 2009). The section Didymobulbos comprises about 40 species including G. lacaitae, and has its maximum diversity in the Mediterranean basin (Tison et al. 2013). Gagea species are geophytes, a typical escapefire strategy largely distributed in those ecosystems (Diadema, Médail, and Bretagnolle 2007; Rundel et al. 2018). In the south of France, the genus is represented by 6 species with a Mediterranean distribution, all of them traditionally associated with open-habitats and grazed grasslands. However, the detection of such species is difficult, as they do not flower every year, and their gramineous-like leaves allow them to mimic grassy vegetation.

Gagea lacaitae (A.Terracc., 1904) is a nationally protected species in France. It is a stenoMediterranean endemic which occurs in different countries across the western Mediterranean basin: Algeria, Spain, France, Italy, Morocco and Tunisia (Peruzzi and Orsenigo 2016; Ferrer Gallego et al. 2007). In France, the species occurs all around the Mediterranean Sea and extends its distribution up to a hundred kilometers inland (SILENE 2019; SIFlore 2019). Despite being quoted as "least concern" at global scale by Peruzzi and Orsenigo (2016), G. lacaitae has seriously declined in the south of France (Peruzzi and Orsenigo 2016) where it has been extensively impacted by urbanization and habitat closing (Fontes 2018; Plassard, Barreau, and Andrieu 2016; Cruon 2008; Danton and Baffray 1998). Thus, its protection status has induced systematic considerations in regulatory studies related to urbanization projects. However, conservation practices have suffered from a global lack of ecological knowledge, and most conservation actions have been designed to restore open habitats mechanically or through grazing.

In regard to conservation issues related to this protected species and its known dependence on open habitats, the recent discovery of several new localities of this typical open-habitat species in forested situations has caught our attention. The presence of large populations within small forest clearings illustrates the lack of precise knowledge about the autecology and chorology of the species. Thus, the objective of this study is to improve our understanding of the species ecology in order to support effective conservation plans. To do so, we have analyzed the variation in the ecological niche of G. lacaitae between two different ecological situations, i.e. open xeric grasslands (open) or forest clearings (closed), focusing on fine-scale ecological variables. First, we studied the biotic component of the niche and investigated community composition and structure. We characterized the species composition between the two situations and analyzed the vegetation structure by comparing total vegetation cover, community diversity and cover of G. lacaitae. Second, we analyzed the abiotic component of the niche by comparing soil characteristics and variables of the micro-habitat structure.

\section{Material and methods Target species}

Gagea lacaitae is a bulbous species that belongs to the Liliaceae family and produces few yellow flowers at the end of winter (around February-March) (Figure 1). The species is considered clonal and sterile (Peruzzi and Orsenigo 2016; Tison et al. 2013) but commonly produces underground or aerial little bulblets as an asexual dispersal vector.

Gagea lacaitae is mainly known from Mediterranean open xeric grasslands where it is often observed in bare soil and open rocky places (Peruzzi and Orsenigo 2016; Tison, Jauzein, and Michaud 2014). While G. lacaitae is known to live in thermophilous xeric habitats, some authors have mentioned that it tolerates partial shading (Cruon 2008; Tison, Jauzein, and Michaud 2014; Danton and Baffray 1998).

\section{Study area and sampling design}

The study was carried out on the Languedoc plain, in the south of France, characterized by a Mediterranean climate, with dry and warm summer and moist cold winter (Thompson 2005). The Languedoc plain corresponds more precisely to a cool winter and wet variant of the Mediterranean climate (Lepart, Fonderflick, and Marty 2014).

Two different environmental contexts were studied: open xeric grasslands and forest clearings habitats, according to the most current and accurate soil land use typology (SIG-LR 2010). Here the first category corresponds to the priority habitat 6220* "Pseudo-steppe with grasses and annuals (Thero-Brachypodietea)" (Figure 2). This habitat is characterized by high species richness (especially for therophytes) but is frequently dominated by Brachypodium retusum (Pers.) P.Beauv. (Bensettiti et al. 2005), a perennial xerophytic herb. The second ecological context corresponds to the habitat 9340 "Quercus ilex and Quercus rotundifolia forests". It is an evergreen forest ecosystem dominated by Quercus ilex L. growing mainly on shallow soils previously grazed and abandoned during the last century (Debussche, Lepart, and Dervieux 1999). G. lacaitae populations were found growing in forest clearings of variable sizes, ranging from 10 to $200 \mathrm{~m}^{2}$ (Figure 2). 


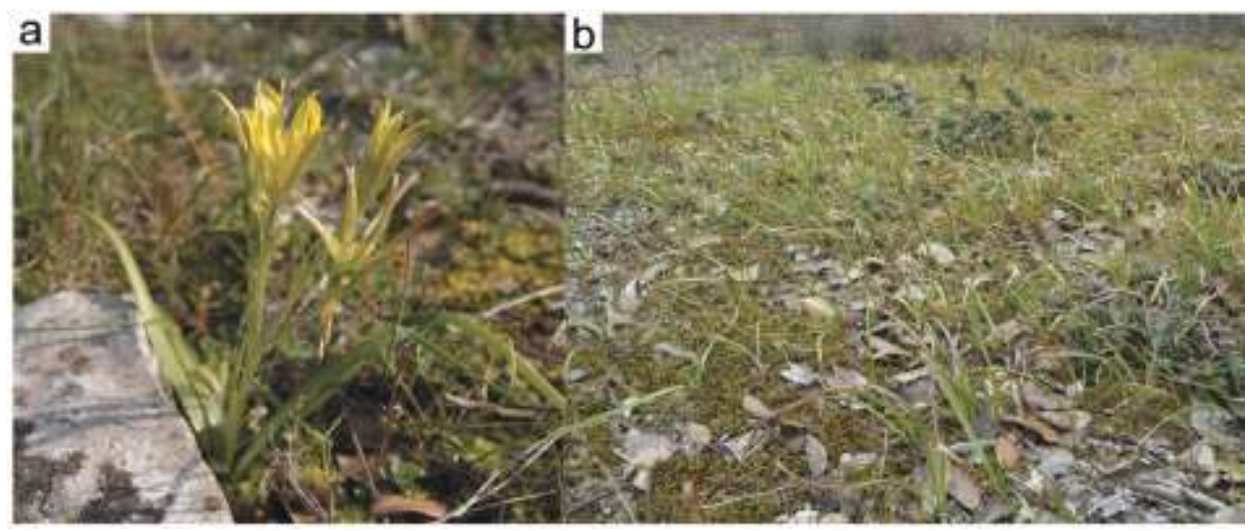

Figure 1. Pictures of Gagea lacaitae: (a) flowering individual (Castries, 2012/03/22) and (b) vegetative population (Junas, 2014/ 03/11), (C H. FONTES.

We sampled eight sites in forest clearings, based on known occurrences of G. lacaitae (SILENE 2019) and new recently discovered localities (authors observations). They represent all the populations known to be present within forest. Then, we selected the eight closest known sites in an open context, totaling 16 sampling sites (Figure 3, Table 1). The habitat category was determined from land-use maps (SIG-LR 2010), and confirmed by photointerpretation (from Bing imagery CMicrosoft Corporation, accessed in February 2017) and field measurements (annex 1).

\section{Protocol and vegetation parameters}

In each sampling site, we performed three vegetation and environmental surveys on $1 \mathrm{~m}^{2}$ quadrats between $27 / 03 / 2017$ to $03 / 04 / 2017$, for a total of 48 plots. In each site, the distance between plots was 1 to $5 \mathrm{~m}$, depending on the population area. We recorded the list of taxa within each quadrat during 15 minutes and visually assessed their percentage coverage. We considered that vegetation and species cover represented a valuable proxy for abundance (Garnier, Navas, and Grigulis 2016). We then calculated the Shannon diversity index H (Shannon and Weaver 1964) and the total vegetation cover per quadrat. Finally, we calculated the number of species for each biological form (Raunkiær 1934) according to Tison, Jauzein, and Michaud (2014) present in the two different ecological contexts (i.e. open xeric grasslands and forest clearings).

We collected similar information on the cover of seven environmental parameters, namely total vegetation, lichens, mosses, bare soil, litter, stones, and rocky outcrop.

In each quadrat, we took a soil sample to a depth of $5 \mathrm{~cm}$. Each sample was dried at $40^{\circ} \mathrm{C}$ for $48 \mathrm{~h}$, then sieved at $2 \mathrm{~mm}$ and stored before analysis. After mixing $10 \mathrm{~g}$ of dry soil with $20 \mathrm{~mL}$ of distilled water, we blended the solution for $20 \mathrm{~min}$, separated phases using a centrifuge (10 $\mathrm{min})$, and measured $\mathrm{pH}$ and conductivity in the supernatant at room temperature (ca. $20^{\circ} \mathrm{C}$ ), using a Eutech Cyberscan (Papuga et al. 2018). Water-retention capacity was calculated as the percentage of water remaining in previously $40^{\circ} \mathrm{C}$ dried soil by again drying the sample at $110^{\circ} \mathrm{C}$ for $5 \mathrm{~h}$. Organic matter was then estimated as the percentage of matter lost after burning a dried sample at $500^{\circ} \mathrm{C}$ for $5 \mathrm{~h}$ (Papuga et al. 2018).

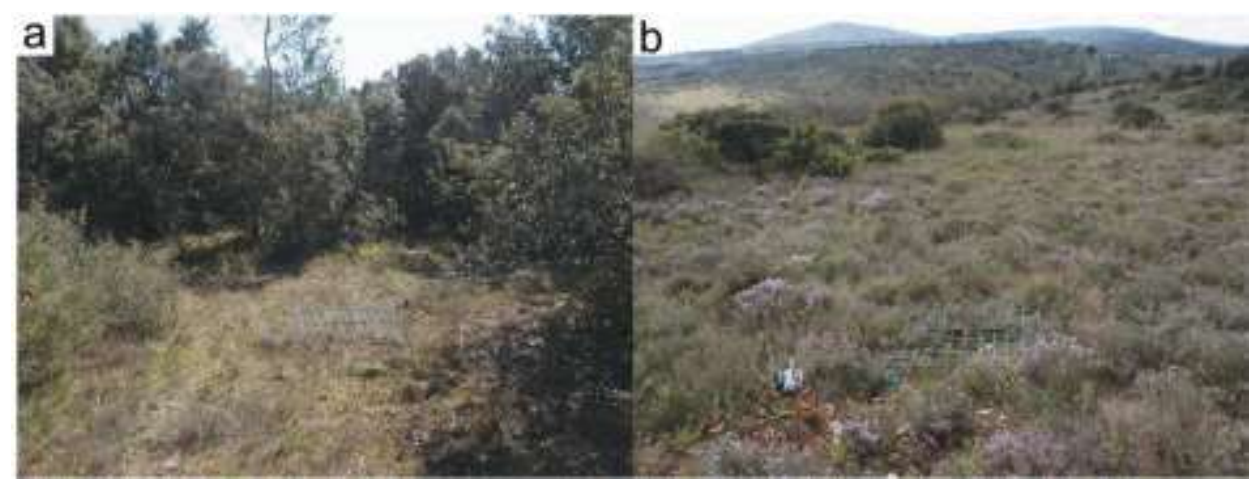

Figure 2. Pictures of the two environmental situations studied: (a) forest clearing (Beaulieu, 2017/03/04) and (b) open xeric grassland (St-Jean-de-Védas, 2017/02/27), @ H. FONTES. 


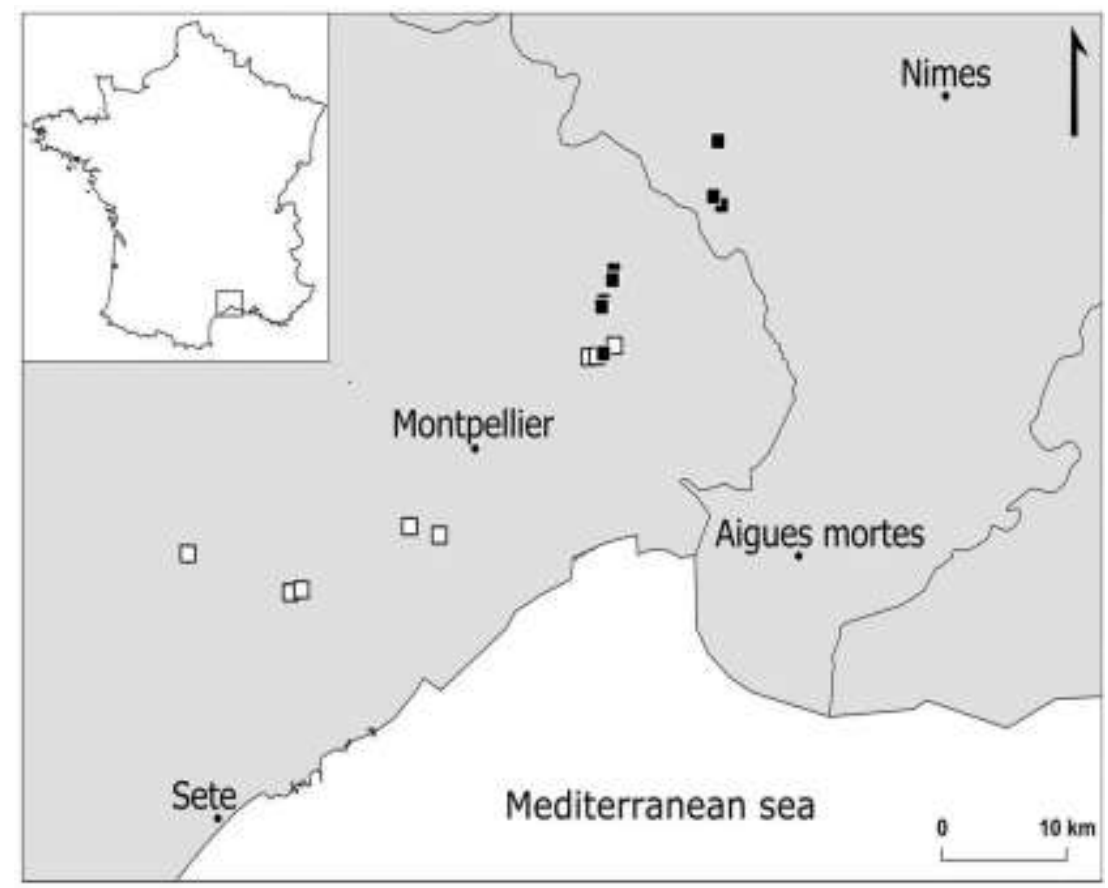

Figure 3. Map of the 16 sampling sites; black and white squares correspond to closed (forested) and open situations, respectively. Administrative areas are departmental limits.

\begin{tabular}{|c|c|c|c|c|c|c|}
\hline Population & Date & Environmental & Town & Localization & X (WGS84) & Y (WGS84) \\
\hline 1 & $2017 / 04 / 03$ & Closed & Beaulieu & Les pins & 4.01434 & 43.7231 \\
\hline 2 & 2017/04/03 & Closed & Beaulieu & Bois de Ginestet & 4.01305 & 43.71699 \\
\hline 3 & $2017 / 03 / 28$ & Closed & Castries & La vigne morte & 4.00413 & 43.67073 \\
\hline 4 & 2017/04/02 & Closed & Junas & Mont redonnet & 4.12087 & 43.76400 \\
\hline 5 & 2017/04/02 & Closed & Junas & Le pied du Cade & 4.11280 & 43.76948 \\
\hline 6 & 2017/04/01 & Closed & Sussargues & Font d'Armand & 4.00407 & 43.70363 \\
\hline 7 & 2017/04/01 & Closed & Sussargues & Bois de la Plaine & 4.00232 & 43.70020 \\
\hline 8 & 2017/04/02 & Closed & Villevielle & Bois Negre & 4.11733 & 43.80423 \\
\hline 9 & $2017 / 03 / 27$ & Open & Aumelas & Bergerie de & 3.59341 & 43.54479 \\
\hline 10 & $2017 / 03 / 28$ & Open & Castries & Les Sauredes & 3.98974 & 43.66846 \\
\hline 11 & $2017 / 03 / 28$ & Open & Castries & Plaine du Mas de & 4.01513 & 43.67569 \\
\hline 12 & 2017/04/03 & Open & Castries & Le roc tombe & 3.99741 & 43.66892 \\
\hline 13 & $2017 / 03 / 27$ & Open & Montbazin & Pelouses des & 3.69480 & 43.52029 \\
\hline 14 & 2017/03/27 & Open & Montbazin & Pelouses des & 3.70553 & 43.52208 \\
\hline 15 & $2017 / 03 / 27$ & Open & St Jean de & Garrigues de la & 3.84198 & 43.55652 \\
\hline 16 & $2017 / 03 / 27$ & Open & St Jean de & Garrigues de la & 3.81266 & 43.56207 \\
\hline
\end{tabular}

Table 1. location of sampled sites and sampled date.

\section{Statistical analysis}

\section{Vegetation composition and structure}

To compare the composition of communities between the two situations we performed a Principal Coordinate Analysis (PCOA) based on species presence/absence in plots and used the Sorensen's index to calculate the ecological distances matrix. To test for a statistical difference between the two contexts, we applied a nonparametric Manova based on a permutation test (package vegan, function adonis, 999 permutations).

Then, we compared the structure of the vegetation with a focus on six different components (Shannon diversity, total vegetation cover, frequencies of typical open xeric grasslands species, frequencies of typical forest species, the cover of each biological form, and G. lacaitae cover). We tested for differences in the cover of biological forms between open xeric grasslands and forest clearings contexts with a Chi-square

test. Then, we tested for a difference in Shannon diversity, frequencies of typical open xeric grasslands species, frequencies of typical forested species total vegetation cover and G. lacaitae cover between the two situations. The 
first two variables were normally distributed (tested with a Shapiro test), so we applied a student t-test; the four last variables did not meet the normality assumption so we ran a non-parametric Wilcoxon test.

\section{Micro-habitat and abiotic characteristics of the niche}

To compare the structure and soil characteristics of the niche between the two situations at the plot scale ( $\left.1 \mathrm{~m}^{2}\right)$, we ran two Principal Component Analyses (PCA). The first was based on seven mesological variables, evaluated as the cover of total vegetation, lichens, mosses, bare soil, litter, stones, and bare rocks. The second aimed at analyzing the soil components and used the following parameters: organic matter, water retention capacity, $\mathrm{pH}$ and conductivity.

All statistical analysis was performed with $R$ software v.3.3.2 ( $R$ Development Core Team 2015). Multivariate analyses were run with the ade4 package (Chessel, Dufour, and Thioulouse 2004).

\section{Results}

\section{Vegetation composition and structure}

The communities co-occurring with Gagea lacaitae were characterized by a high taxonomic diversity and a total of 195 taxa were observed during the floristic surveys. The average species richness observed in $1 \mathrm{~m} 2$ quadrats was 34.3 ( \pm 5.3 ) species. In both open xeric grasslands and forest clearings, the most frequent and abundant species observed (Table 2) are considered to be open Mediterranean xeric grassland species in the south of France (Tison, Jauzein, and Michaud 2014). By comparison, forest species inventoried in quadrats were rarer with Quercus ilex L. ( $21 \%$ co-occurrence with G. lacaitae), Asparagus acutifolius L. ( 6\%) and Pinus halepensis Mill. ( 4\%). Thus, we found that the frequency of open habitat species was not different between the two situations ( $W=16,897, p=0.28)$, while the frequency of forest species was higher in forest clearings $(\mathrm{W}=24.5, \mathrm{p}<0.05)$.

The Principal Correspondence Analysis (Figure 4) showed on axis 1 an important shift in community composition between forest clearings and open xeric grasslands (contribution: 14.52\%). These two environ-mental contexts best explain the variation in the composition of the $G$. lacaitae community, as validated by a Manova permutation test $\left(p<0.001, R^{2}=0.17, F=9.32\right)$.

The Chi-square test revealed no significant difference in the distributions of the biological forms between open xeric grasslands and forest clearings contexts (X-squared $=7.03 ; \mathrm{df}=4 ; \mathrm{p}=0.13$ ). Forest clearings or open xeric grasslands contexts had no influence on $\mathrm{H}$ diversity, as validated with t-test ( $\mathrm{df}=43.82, \mathrm{p}=0.46)$ (Figure 5).

Differences explained by the axis 1 of the PCoA (presence/absence on floristic data, Figure 4) were not related to a change in plot diversity (according to precedent t-test) but to a change in composition between plots. Total vegetation cover was significantly higher in open xeric grasslands than in forest clearings context $(\mathrm{df}=43.29, \mathrm{p}<$ 0.001). However, G. lacaitae cover was not different in the two contexts ( $W=227, p=0.16$ ) (Figure 5).

\section{Micro-habitat and abiotic characteristics of the niche}

Within plot abiotic conditions showed an important shift between open xeric grasslands and forest clearings contexts (Figure 6), highlighted by axis 1 of the PCA. These two environmental contexts best explain the abiotic variation of G. lacaitae niche.

Axis 1 (contribution: 34\%) was positively correlated with vegetal and stone cover, corresponding to open xeric grasslands, and negatively correlated with mosses, lichens and litter cover, corresponding to forest clearings. The second axis (contribution: 20.05\%) was principally correlated with organic matter and, to a lesser extent, soil water retention capacity, rocky outcrop, and bare soil. This highlights a low correlation between soil propriety (organic matter and water retention capacity) and the ecological context. Rocky outcrop and bare soil were evenly distributed between open xeric grasslands or forest clearings.

Focusing on soil analysis, the niche extent of the forest clearings group was larger than the one of the open xeric grasslands group and includes it (Figure 7). Axis 1 (contribution: 67.89\%) was negatively correlated with organic matter, conductivity and water retention capacity. Axis 2 (contribution: 19.76\%) was positively correlated with $\mathrm{pH}$. 


\begin{tabular}{|c|c|c|}
\hline Environmental situation & $\begin{array}{c}\text { Most frequent } \\
\text { (\% of co-occurrence) }\end{array}$ & $\begin{array}{c}\text { Most abundant } \\
\text { (\% of mean recovery in quadrats) }\end{array}$ \\
\hline \multirow[t]{5}{*}{ Open habitat } & Crepis sancta $(L)$ Bomm. $(96 \%)$ & Brachypodium retusum (Pers.) P.Beauv. (17.5\%) \\
\hline & Thymus vufgoris L (88\%) & Thymus wigaris L. (12.6\%) \\
\hline & Canvolvulus cantabrica L. (7996) & Gepis sancta (L) Bornm. (4.7\%) \\
\hline & Brochypodium retusum (Pers.) P.Beauv. (75\%) & Plantago lagapus L $(2.7 \%)$ \\
\hline & Allium roseum L $(66 \%)$ & Vilpia $\$ .(2.2 \%)$ \\
\hline \multirow[t]{5}{*}{ Closed habitat } & Cerostium pumilum Curtis (96\%) & Sedum sediforme (Jacq.) Pau (3.1\%) \\
\hline & Lysimachia Iinum-stellatum L. (92\%) & Thymus vigaris L. (2.4\%) \\
\hline & Crepis sancta $(L)$ Bornm. $(83 \%)$ & Crepis sancta (L) Bornm. (2.2\%) \\
\hline & Arenaria leptociados (Rchb.) Guss, $(83 \%)$ & Carex halleniana Asso $(1.8 \%)$ \\
\hline & Vulpia sp. (79\%) & Fumana thymifalia $\{$ L.) Spach ex Webb (1.2\%) \\
\hline \multirow[t]{5}{*}{ Open and closed habitat } & Crepis sancta (L.) Bornm. (89.6\%) & Brachypodium refusum (Pers.) P.Beauv. $(9.2 \%)$ \\
\hline & Thymus vulgaris L $(72.9 \%)$ & Thymus wigaris L. (7.4\%) \\
\hline & Lysimachia linum-steflatum L. (70.8\%) & Crepis sancta (L.) Bornm. $(3,4 \%)$ \\
\hline & Cerastium pumilum Curtis $(66.7 \%)$ & Sedum sediforme (Jacq.) Pau (1.9\%) \\
\hline & Sedum sediforme (lacq.) Pau $(64.6 \%$ ) & Plantago lagapus L. (1.4\%) \\
\hline
\end{tabular}

Table 2. Most frequent and most abundant species inventorying in 48 quadrats $\left(1 \mathrm{~m}^{2}\right)$. The results are detailed according to the environmental context (Open and closed habitat and with total data).

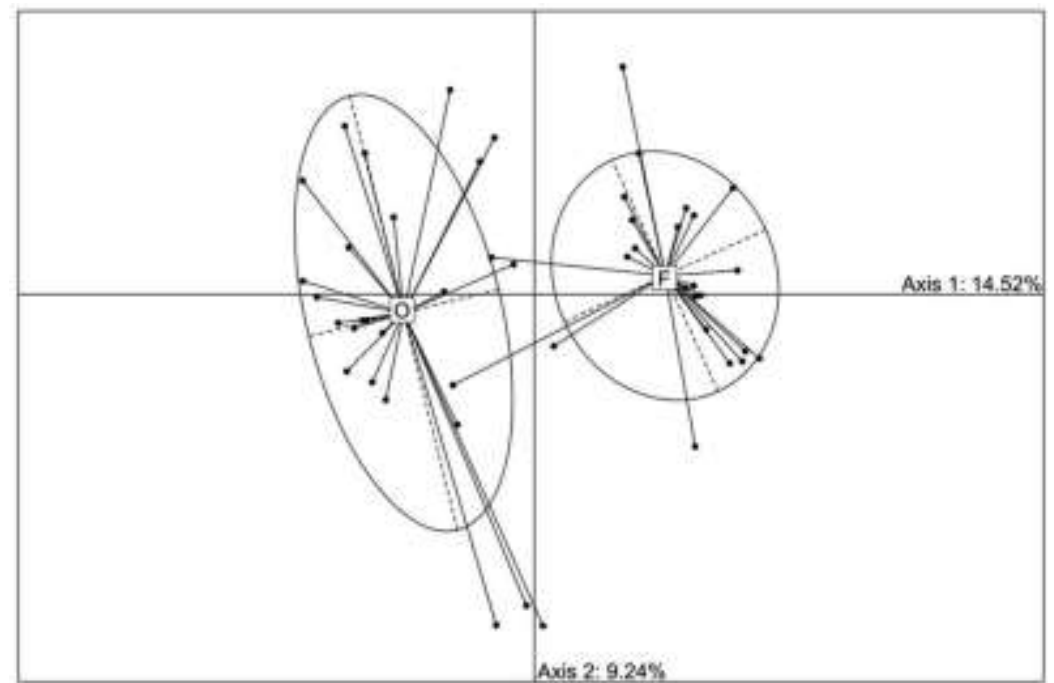

Figure 4. Analysis of G. lacaitae's ecological niche based on vegetal community composition. 194 species were inventoried in 48 quadrats and then analyzed using a Principal Coordinates Analysis (PCoA) based on a Jaccard distance matrix. Explained variance is mentioned on the figure for each axis (\%). The two environmental contexts (open xeric grassland and forest clearing, $\mathrm{O}$ and $\mathrm{F}$ ) are represented by ellipses that encompass $75 \%$ the individuals. $\mathrm{A}$ shift in community composition is observed between open xeric grasslands and forest clearing contexts.
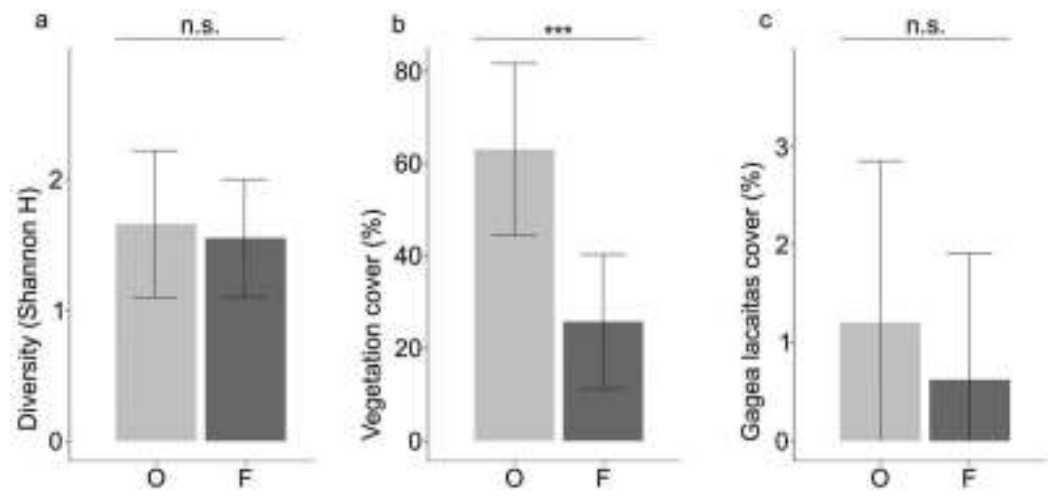

Figure 5. Comparison of three community variables between open xeric grasslands (O) and forest clearing (F) situations. Panel (a) presents Shannon diversity index, panel (b) presents the total vegetation cover and panel (c) the cover of G. lacaitae. Values are expressed as means \pm standard error. Statistical threshold are $*$ : $p$-value $<0.05 ;{ }^{* *}: p$ value $<0.01 ; * *$ : $p$-value $<0.001$ and $n$. s.: non-significant. The only significant difference observed is for the total vegetation cover which is lower under closed context. 

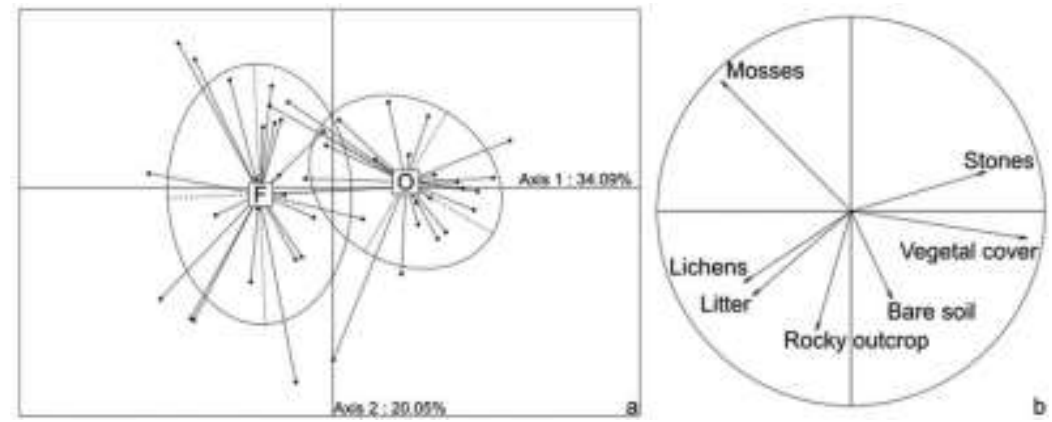

Figure 6. Analysis of G. lacaitae's ecological niche based on microhabitat structure. Seven variables (surface covered by mosses, lichens, litter, rocky outcrop, ground, vegetal cover and stones) measured on 48 samples were treated with a Principal Component Analysis. Explained variance is mentioned on the figure for each axis (\%). Panel (a) represents the projection of individuals (i.e. quadrats) on the two first axes. Ellipses represent $70.8 \%$ of the points grouped by their environmental contexts (open xeric grasslands and forest clearing, $\mathrm{O}$ and $\mathrm{F}$ ). Panel (b) represents the correlation circle of the seven abiotic variables projected on the same two axes. The structure of the microhabitat of Gagea lacaitae show significant change between open xeric grasslands and forest clearing context. Open xeric grasslands is mostly associated with stones and vegetation cover whereas forest clearing is mostly associated with mosses, lichens and litter.
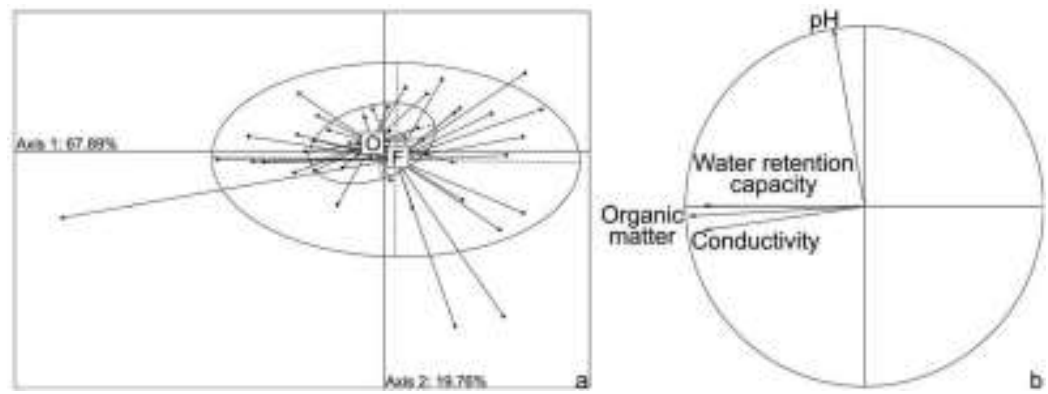

Figure 7. Analysis of G. lacaitae's ecological niche based on four soil variables (pH, conductivity, organic matter and water redemption capacity). Explained variance is mentioned on the figure for each axis (\%). Panel (a) presents a projection of individuals (i.e. 48 quadrats) on the two first axes. Ellipses represent $72.9 \%$ of the points grouped by their environmental contexts (open xeric grasslands and forest clearing, $\mathrm{O}$ and $\mathrm{F}$ ). Panel (b) represents the correlation circle of the seven abiotic variables projected on the same two axes. The niche breadth of the forest clearing group is larger than the one of the open xeric grasslands group.

\section{Discussion}

To construct appropriate conservation and management programs, it is essential that we understand the ecological requirements of rare plants so that we can orient our surveys, choose suitable habitats, and identify potential threats. Here we present evidence of an unknown niche for a Mediterranean endem ic geophyte, Gagea lacaitae. This species, usually found in open xeric pastures, has been detected within holm oak woods, which have recently recolonized former grasslands. This has enlarged our perspective on the niche it has realized in terms of soil characteristics, which indicates that this species could survive in different ecological contexts (i.e. open xeric grassland and forest clearings). Therefore, we discuss the conservation significance of such niche shifts in terms of autecology and implications for conservation.

\section{A truncated view of the niche}

Through our study, we have highlighted several similarities in the niche of G. lacaitae in both open xeric grasslands and forest clearings. First, plant communities show a similar functional structure in terms of biological forms and are dominated by therophytes. Mean Shannon diversity index is not significantly different between the two contexts and G. lacaitae abundance (i.e. cover) does not show any significant difference. Yet, our study highlights a significant shift in $\mathrm{G}$. lacaitae niche between open xeric grasslands and forest clearings for the abiotic compartment (Figure 6) and the composition of its associated plant community. This change in community composition reflects the expected prevalence of forestland species within forest clearings. However, some of this difference may reflect the geographical gradient of our sampling design which reinforced the shift in composition from open xeric grasslands to forest clearings. That is, the matrix is more dominated by forests toward the northeast, potentially changing the local species pool. 
Regarding soil conditions, we haven't observed any shift in the mean value of soil parameters (Figure 7), but we show that ecological niche extend is wider in forest clearings. While one can expect an increase of organic matter caused by woody colonization in dry grasslands (Jackson et al. 2002), some of the forested plots show the lowest organic matter content of the study. This points out the heterogeneity of forest clearings that could constitute suitable micro-habitats for the persistence of various species. Indeed, while holm oak forests might appear as homogeneous vegetation of low biodiversity value, they contain localized heterogeneous structures (Quezel and Médail 2003) including clearings, paths of trampled soils, rocky outcrops or even cliffs and stream, which constitute many micro-habitats of interest.

\section{Origin and persistence of $\mathrm{G}$. lacaitae in forested habitat}

The observation of $\mathrm{G}$. lacaitae in forest context raises questions regarding the origin of its presence. Before the first evidence of human impact on landscapes around 8000 years ago, most of the Mediterranean basin was occupied by forested ecosystems, including oak forests and current Mediterranean landscapes mosaic is explained by the millenary interactions between human activities and environmental conditions (Quezel and Médail 2003; Blondel 2006). Since the 1950s, extensive agricultural and pastoralism decline has led to the colonization of grazed grasslands by trees in the north-west part of the Mediterranean basin, among which Quercus ilex L. is one of the most widespread (Lepart, Fonderflick, and Marty 2014; Quezel and Médail 2003). This is supported by historical aerial photographs (1946-1980, available for consultation at the French national institute of geography website https://remonterle temps.ign.fr//) that show open grasslands in places that we considered currently as forested in our study. This highlights the dynamic aspect of vegetation succession, and the recent colonization of forest is likely to have reduced and fragmented previously open habitats into smaller fragments dominated by forest matrix (Fonderflick et al. 2007; Debussche, Lepart, and Dervieux 1999).

While we cannot assess long term population trends with our dataset, we support that population investigated here are not rare elements on the verge of extinction. Indeed, our study has revealed that no significant difference in G.lacaitae abundance was observed between the two situations, some of the highest density plots being located in forests. Additionally, the analysis of plant communities has shown that forest clearings where G. lacaitae is present were dominated by a pool of open habitat species that form communities equally diversified than those in open xeric grasslands.

While forested habitats are known to affect the reproduction success of several Mediterranean geophytes (Andrieu, Thompson, and Debussche 2007; Andrieu et al. 2013), G. lacaitae keeps producing bulblets even under shaded conditions ( $\mathrm{H}$. Fontes personal observation). This sterile but non-apomictic situation is known in at least one other Gagea species (Gagea spathacea (Hayne), Salisb.), a typical forest species probably dispersed by fauna through epizoochory by substrate translocation (Pfeiffer et al. 2012). The dispersal action of wild boars (Sus scrofa L.) on vascular plants has already been highlighted (Heinken et al. 2006) and could be a vector of G. lacaitae dispersal. Therefore, thanks to our field observations and previous results, we assume that microhabitat occupancy within forested-habitats reflects various ecological processes. Abiotic conditions (climatic effects and soil conditions) can limit tree colonization (Henry 2009) and could be a favorable habitat for G. lacaitae. Additionally, repeated disturbances can open up areas, that G. lacaitae could colonize. In this context, wild boar (Sus scrofa L.) could play a key role as a major cause of soil disturbance (Barrios-Garcia and Ballari 2012). More generally, the disturbance and grazing effects of large wild fauna on landscape heterogeneity could allow grasslands to persist without human's interventions (Bengtsson et al. 2000; Quezel and Médail 2003; Vera 2000). Likewise, fire is known to be an important factor to maintain grasslands habitats, which can lead to the formation of a mosaic landscape (Bengtsson et al. 2000; Quezel and Médail 2003). The interaction of fire and grazing could allow grasslands ecosystems to persist at different spatial scales i.e. from landscape

to local forest patches (Horčičkovâ, Brůna, and Vojta 2019). However, the spatial grain of landscape heterogeneity remains poorly understood (Pausas and Ribeiro 2017; Pausas and Vallejo 1999), despite its key role in ecological processes such as dispersal to maintain population dynamics (D'Antraccoli et al. 2019).

\section{Integrating forests within conservation}

Appropriate inventories are essential for biodiversity conservation as they allow to correctly estimate the rarity of a taxon on a territory. The lack of knowledge concerning $\mathrm{G}$. lacaitae's ecological niche can induce a severe underestimation of the species occurrence. In fact, this species is difficult to detect, because of its discreet appearance and its phenology (it grows during late winter - early spring, when botanists have reduced activities). Moreover, historically managed Quercus ilex L. forests are usually considered of low ecological interest, and are poorly known by naturalists due to their apparent homogeneity (Gil-Tena, Saura, and Brotons 2007). Such 
constraints may bias what we know of G. lacaitae's distribution, and to underestimate the conservation value of those ecosystems. Ultimately, this has strong implications in regulatory studies as it involves a risk of accidental destruction. In addition, if translocations are required, it is important to have a good overview of the species' niche in order to optimize the site selection, a crucial point in such experiments (Godefroid et al. 2011). More generally, our study highlights the interest to study fine scale disturbances and abiotic effects on Mediterranean forest ecosystems.

\section{Conclusion}

The decrease of open habitats due to colonization by woody species is considered as a major threat to plant biodiversity. Many species are closely associated with traditional agropastoralism, especially in the northern Mediterranean basin. Our study does not call into question the interest of open habitat conservation but emphasizes that wooded areas can be heterogeneous landscapes, not only suitable for strictly forest communities. We have shown that typical open-places species can survive in forest clearings, including the rare and protected Gagea lacaitae which experiences a wider niche in terms of soil characteristics. The lack of attention to young holm oak forests has lead ecologist to underestimate the extent of the species' ecological niche, in terms of habitat structure, community composition, and soil characteristics. Relevant conservation plans should include forested ecosystems, in order to understand their role in the persistence of these open-habitats species in a changing landscape. In particular,

the conservation of such ecosystems and their natural processes (disturbance regimes as fire or grazing, zoochory, vegetation dynamics) in order to preserve this micro-habitat heterogeneity is a key step toward global landscape conservation (Bissonette 1997).

\section{Acknowledgments}

We thank Perrine Gauthier, François Mesléard and Patrick Grillas for insightful discussions on the topic. Soil analyses were performed at the "Plateforme d'Analyses Chimiques en Ecologie ", technical facilities of the CeMEB-Labex in Montpellier. We thank Virginie Pons for running some mea-sures, and Bruno Buatois, Raphael Leclerc and Nicolas Barthes for their support. We thank one anonymous reviewer and Donald M. Waller for their useful comments, that significantly improved the quality of the manuscript. Special thanks go to Mireille Guillaume and Charlie La Via for improving English.

\section{Disclosure statement}

No potential conflict of interest was reported by the authors.

\section{Notes on contributors}

Hugo Fontes is a research engineer, working in ecological restoration and plant conservation at the community level. $\mathrm{He}$ is specialized in wetland conservation and has a strong background on terrestrial plant ecology in Mediterranean ecosystems. He initiated this study, realized the field work, the analyses and wrote the major part of the article.

Antoine Gazaix is a Ph.D. student working on the conservation of Mediterranean temporary ponds and endangered flora. He works at the interface between fundamental research in ecology and applied conservation. He participated actively to the conception of the protocol, the field work, the analyses and to writing.

Guillaume Papuga is a researcher working on plant ecology, evolution and conservation in Mediterranean ecosystems. His work is related to rare species conservation, ecosystems functioning and biogeography of the Mediterranean basin. He participated actively to the conception of the protocol, the analyses and to writing.

\section{ORCID}

Hugo Fontes http://orcid.org/0000-0002-7826-6680

Antoine Gazaix http://orcid.org/0000-0002-0782-274X

Guillaume Papuga http://orcid.org/0000-0002-7803

2219

\section{References}

Andrieu, E., H. Fréville, A. Besnard, V. Vaudey, P. Gauthier, J. D. Thompson, and M. Debussche. 2013. "Forestcutting Rapidly Improves the Demographic Status of Paeonia officinalis, a Species Threatened by Forest Closure." Population Ecology 55 (1): 147-158. doi:10.1007/s10144-012-0346-1.

Andrieu, E., J. D. Thompson, and M. Debussche. 2007. "The Impact of Forest Spread on a Marginal Population of a Protected Peony (Paeonia officinalis L.): The Importance of Conserving the Habitat Mosaic." Biodiversity and Conservation 16 (3): 643-658. doi:10.1007/s10531-005-2357-0.

Barrios-Garcia, M. N., and S. A. Ballari. 2012. "Impact of Wild Boar (Sus scrofa) in Its Introduced and Native Range: A Review." Biological Invasions 14 (11): 2283-2300. doi:10.1007/s10530-012-0229-6. 
Bengtsson, J., S.-G. Nilsson, A. Franc, and P. Menozzi. 2000. "Biodiversity, Disturbances, Ecosystem Processes and Sustainability of European Forests." Forest Ecology and Management 132: 39-50. doi:10.1016/S0378-1127 (00)00378-9.

Bensettiti, F., B. Boullet, C. Chavaudret-Laborie, and J. Deniaud. 2005. “Cahiers D'habitats Natura 2000. Connaissance Et Gestion Des Habitats Et Des Espèces D'intérêt Communautaire: Habitats Agropastoraux [Natura 2000 Habitat Notebooks. Knowledge and Management of Habitats and Species of Community Interest: Agropastoral Habitats]." Paris : La Documentation Française 2: 371-394.

Bissonette, J. A. 1997. Wildlife and Landscape Ecology: Effects of Pattern and Scale, 418. New York: Springer edition.

Blondel, J. 2006. "The 'design' of Mediterranean Landscapes: A Millennial Story of Humans and Ecological Systems during the Historic Period." Human Ecology 34 (5): 713-29. doi:10.1007/s10745-006-9030-4.

Blondel, J., J. Aronson, J. Y. Bodiou, and G. Boeuf. 2010. The Mediterranean Region, Biological Diversity in Space and Time, 392. 2nd ed. Oxford: Oxford edition.

Chessel, D., A. Dufour, and J. Thioulouse. 2004. "The Ade4 Package - I: One-Table Methods." R News 4 (1): 5-10.

Cruon, R. (under the direction of). 2008. Le Var Et Sa Flore: Plantes Rares Ou Protégées [the Var and Its Flora: Rare or Protected Plants]. Turriers: Naturalia Publications.

D’Antraccoli, M., F. Roma-Marzio, A. Carta, S. Landi, G. Bedini, A. Chiarucci, and L. Peruzzi. 2019. “Drivers of Floristic Richness in the Mediterranean: A Case Study from Tuscany." Biodiversity and Conservation 28: 1411- 1429. doi:10.1007/s10531-019-01730-x.

Danton, P., and M. Baffray. 1998. Inventaire Des Plantes Protegées En France [Inventory of Protected Plants in France]. Paris: Nathan edition.

Debussche, M., J. Lepart, and A. Dervieux. 1999. "Mediterranean Landscape Changes: Evidence from Old Postcards." Global Ecology and Biogeography 8 (1): 3-15. doi:10.1046/j.1365-2699.1999.00316.x.

Diadema, K., F. Médail, and F. Bretagnolle. 2007. "Fire as a Control Agent of Demographic Structure and Plant Performance of a Rare Mediterranean Endemic Geophyte." Comptes Rendus Biologies 330 (9): 691-700. doi:10.1016/j.crvi.2007.06.003.

Falcucci, A., L. Maiorano, and L. Boitani. 2007. "Changes in Land-use/land-cover Patterns in Italy and Their Implications for Biodiversity Conservation." Landscape Ecology 22 (4): 617-631. doi:10.1007/ s10980-0069056-4.

Farris, E., S. Pisanu, G. Ceccherelli, and R. Filigheddu. 2009. "Effects of the Management Regime on the Performance of the Endangered Mediterranean Centaurea horrida Badarô (Asteraceae)." Journal for Nature Conservation 17 (1): 15-24. doi:10.1016/j. jnc.2008.10.002.

Ferrer Gallego, P. P., E. Laguna Lumbreras, S. Alba Villegas, and J. M. Tison. 2007. "Sobre La Presencia De Gagea lacaitae A. Terracc. (Liliaceae) En La flora Valenciana [about the Presence of Gagea lacaitae A. Terracc. (liliaceae) in the Valencian flora]." Acta Botanica Malacitana 32: 1-12.

Fonderflick, J. 2007. “Conséquences De La Fermeture Et De La Fragmentation Des Milieux Ouverts Sur L'avifaune Nicheuse Des Causses [consequences of Open Habitats Closure and Fragmentation to the Breeding Birds of the Causses]." PhD diss., Ecole Pratique des Hautes Etudes.

Fontes, H. 2018. "Gagea lacaitae." In Atlas De La Flore Remarquable Des Bouches Du Rhône: Plantes, Milieux Naturels Et Paysages [Atlas of the Remarkable Flora of the Bouches Du Rhône: Plants, Natural Environments and Landscapes], edited by M. Pires and D. Pavon, 464. Mèze: Biotope editions.

Garnier, E., M. L. Navas, and K. Grigulis. 2016. Plant Functional Diversity: Organism Traits, Community Structure, and Ecosystem Properties. Oxford: Oxford University Press.

Gil-Tena, A., S. Saura, and L. Brotons. 2007. "Effects of Forest Composition and Structure on Bird Species Richness in a Mediterranean Context: Implications for Forest Ecosystem Management." Forest Ecology and Management 242: 470-476. doi:10.1016/j. foreco.2007.01.080.

Godefroid, S., C. Piazza, G. Rossi, S. Buord, A. D. Stevens, R. Aguraiuja, C. Cowell, et al. 2011. "How Successful are Plant Species Reintroductions?" Biological Conservation 144 (2): 672-682. doi:10.1016/j.biocon.2010.10.003.

Heinken, T., M. Schmidt, G. Von Oheimb, W. U. Kriebitzsch, and H. Ellenberg. 2006. "Soil Seed Banks near Rubbing Trees Indicate Dispersal of Plant Species into Forests by Wild Boar." Basic and Applied Ecology 7 (1): 31-44. doi:10.1016/j.baae.2005.04.006.

Henry, F. 2009. “Origine Et Dynamique À Long Terme D’un Écosystème Herbacé Pseudo Steppique, Le Cas De La Plaine De La Crau (bouches Du Rhône, France) [origin and Long-term Dynamics of a Herbaceous Pseudo Steppe Ecosystem, the Case of the Crau Plain (Bouches du Rhône, France)]." PhD diss., Aix-Marseille 3.

Horčičkovâ, E., J. Brůna, and J. Vojta. 2019. "Wild Boar (Sus scrofa) Increases Species Diversity of Semidry Grassland: Field Experiment with Simulated Soil Disturbances." Ecology and Evolution 9: 2765-2774.

Jackson, R. R., J. L. Jey, G. J. Esteban, T. P. William, and D. H. Wall. 2002. "Ecosystem Carbon Loos with Woody Plant Invasion of Grassland." Nature 418: 623-626. doi:10.1038/nature00910.

Jalut, G., J. J. Dedoubat, M. Fontugne, and T. Otto. 2009. "Holocene circum-Mediterranean Vegetation Changes: Climate Forcing and Human Impact." Quaternary International 200 (1-2): 4-18. doi:10.1016/j. quaint.2008.03.012.

Lavergne, S., W. Thuiller, J. Molina, and M. Debussche. 2005. "Environmental and Human Factors Influencing Rare Plant Local Occurrence, Extinction and Persistence : A 115-year Study in the Mediterranean Region." Journal of Biogeography 32: 799-811. doi:10.1111/ jbi.2005.32.issue-5.

Lenormand, M., G. Papuga, O. Argagnon, M. Soubeyrand, G. De Barros, S. Alleaume, and S. Luque. 2018. "Biogeographical Network Analysis of Plant Species Distribution in the Mediterranean Region." Ecology and Evolution 9 (1): 237-250. 
Lepart, J., J. Fonderflick, and P. Marty. 2014. “Histoire Des Interactions Entre Les Changements D'usage Des Terres Et La Biodiversité [History of Interactions between Land Use Changes and Biodiversity]." In Sciences De La Conservation, edited by M. Gauthier-Clerc, F. Mesleard, and J. Blondel, 376. Louvain-la-Neuve: De Boeck edition.

Mazzoleni, S., G. Di Pasquale, M. Mulligan, P. Di Martino, and F. Rego. 2004. Recent Dynamics of the Mediterranean Vegetation and Landscape. Hoboken, New Jersey: John Wiley \& Sons edition.

Médail, F., and P. Quezel. 1997. "Hot-spots Analysis for Conservation of Plant Biodiversity in the Mediterranean Basin." Annals of the Missouri Botanical Garden 84 (1): 112-127. doi:10.2307/2399957.

Mesléard, F., N. Yavercovski, G. Lefebvre, L. Willm, and A. Bonis. 2017. "High Stocking Density Controls Phillyrea angustifolia in Mediterranean Grasslands." Environmental Management 59 (3): 455-463. doi:10.1007/s00267-0160808-x.

Myers, N., R. A. Mittermeier, C. G. Mittermeier, G. A. B. Da Fonseca, and J. Kent. 2000. "Biodiversity Hotspots for Conservation Priorities." Nature 403: 853-858. doi:10.1038/35002501.

Newbold, T., L. N. Hudson, S. L. L. Hill, S. Contu, I. Lysenko, R. A. Senior, L. Bürger, et al. 2015. "Global Effects of Land Use on Local Terrestrial Biodiversity." Nature 520 (7545): 45-50. doi:10.1038/nature14324.

Papuga, G., P. Gauthier, V. Pons, E. Farris, and J. D. Thompson. 2018. "Ecological Niche Differentiation in Peripheral Populations: A Comparative Analysis of Eleven Mediterranean Plant Species." Ecography 41 (10): 1650-1664. doi:10.1111/ecog.03331.

Pausas, J. G., and V. R. Vallejo. 1999. "The Role of Fire in European Mediterranean Ecosystems." In Remote Sensing of Large Wildfires in the European Mediterranean Basin, edited by E. Chuvieco, 228. Berlin, Heidelberg: Springer.

Pausas, J. G., and E. Ribeiro. 2017. "Fire and Plant Diversity at the Global Scale." Global Ecology and Biogeography 26 (8): 889-897. doi:10.1111/geb.2017.26.issue-8.

Perevolotsky, A., and N. G. Seligman. 1998. "Role of Grazing in Mediterranean Rangeland Ecosystems." BioScience 48 (12): 1007-1017. doi:10.2307/1313457.

Peruzzi, L., and S. Orsenigo. 2016. "Gagea lacaitae." The IUCN Red List of Threatened Species.

Pfeiffer, T., A. Klahr, A. Peterson, I. G. Levichev, and M. Schnittler. 2012. "No Sex at All? Extremely Low Genetic Diversity in Gagea spathacea (Liliaceae) across Europe." Fora 207: 372-378.

Plassard, C., D. Barreau, and F. Andrieu. 2016. Atlas De La Flore Patrimoniale De I'Aude [Atlas of Aude Patrimonial Flora]. Mèze: Biotope edition.

Quezel, P., and F. Médail. 2003. Ecologie Et Biogéographie Des Forêts Du Bassin Méditérranéen [Ecology and Biogeography of the Mediterranean Basin's Forests]. Paris: Elsevier edition.

R Development Core Team. 2015. "R: A Language and Environment for Statistical Computing. R Foundation for Statistical Computing." Accessed 16 January 2017. http://www.R-project.org

Raunkiær, C. 1934. The Life Forms of Plants and Statistical Plant Geography. Oxford: Oxford University edition.

Rundel, P. W., M. T. K. Arroyo, R. M. Cowling, J. E. Keeley, R. R. Lamont, J. G. Passas, and P. Vargas. 2018. "Fire and Plant Diversification in Mediterranean-climate Regions." Frontiers in Plant Science 9: 851.

Sala, O. E., F. S. Chapin, J. J. Armesto, E. Berlow, J. Bloomfield, R. Dirzo, E. Huber-Sanwald, et al. 2000. "Biodiversity: Global Biodiversity Scenarios for the Year 2100." Science 287: 1770-1774. doi:10.1126/ science.287.5459.1770.

Schnitzler, A. 2014. "Towards a New European Wilderness: Embracing Unmanaged Forest Growth and the Decolonisation of Nature." Landscape and Urban Planning 126: 74-80. doi:10.1016/j.landurbplan.2014.02.011.

Shannon, C. E., and W. Weaver. 1964. The Mathematical Theory of Communication. Urbana: University of Ilinois press.

SIFlore. 2019. "French Database of National Botanical Conservatory Federation." Accessed February 2019. http://siflore.fcbn.fr/?cd ref=\&r=metro

SIG-LR. 2010. “Occupation Du Sol Languedoc - Roussillon 1999 Et 2006: Guide Technique V1 (réédition Aout 2010) [land Use of Languedoc - Roussillon 1999 and 2006: Technical Guide V1 (reissue August 2010)]."

SILENE. "French Database of National Botanical Conservatories of Mediterranean, Alps, Pyrénées and MidiPyrénées." 2019. Accessed February 2017 and

February 2019. http://flore.silene.eu/index.php?cont= accueil

Thompson, J. D. 2005. Plant Évolution in the Mediterranean. Oxford: Oxford University press.

Tison, J. M., A. Peterson, D. Harpke, and L. Peruzzi. 2013. "Reticulate Evolution of the Critical Mediterranean Gagea sect. Didymobulbos (liliaceae) and Its Taxonomic Implications." Plant Systematics and Evolution 299: 413- 438. doi:10.1007/s00606-012-0731-4.

Tison, J. M., P. Jauzein, and H. Michaud. 2014. Flore De La France Méditerranéenne Continentale [Flora of Continental Mediterranean France]. Turriers: Naturalia Publication.

Vera, F. W. M. 2000. Grazing Ecology and Forest History. New York: CABI Publishing.

Zarrei, M., P. Wilkin, M. F. Fay, M. J. Ingrouille, S. Zarre, and M. W. Chase. 2009. "Molecular Systematics of Gagea and Lloydia (liliaceae; Liliales): Implications of Analyses of Nuclear Ribosomal and Plastid DNA Sequences for Infrageneric Classification." Annals of Botany 104: 125-142. doi:10.1093/aob/mcp103.

\section{Appendix 1: Trees distances}

To environmental contexts, we confirm the forested $(n=24)$ or non-forested $(n=24)$ situation by a field measurement. We measured four distances between trees and each quadrant, towards the four cardinal points. The measurement is realized on the field to the trees 20 meters apart and on GIS, using satellite imagery, to the others. 
Quadrats localized in a forested context, firstly identify by soil occupancy data and aerial photography interpretation, haves an average distance to trees significantly lower that quadrats localized in non-forested context $(5.3 \pm 2.3 \mathrm{~m}$ for closed context against $67.5 \pm 30.4 \mathrm{~m}$ for open context), validated by a Wilcoxon signed rank test ( $\mathrm{k}$ 0.001) (Figure 1).

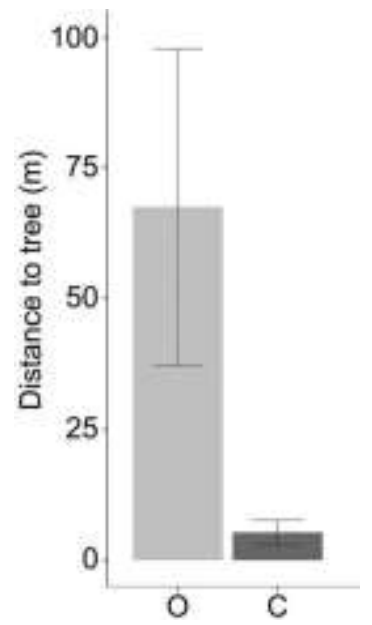

Distance between quadrats and trees in closed (forested) and open context. Values are expressed as means \pm standard error. Significant differences are validated by a wilkoxon test $(p<0.001)$. Values are calculated as means of the four distances between quadrant and trees towards the four cardinal points. 